\title{
RESPONSABILIDADE DAS EMPRESAS QUE PRESTAM SERVIÇOS A TERCEIROS EM FACE DA SAÚDE AMBIENTAL/DO MEIO AMBIENTE DO TRABALHO
}

\section{RESPONSIBILITY OF COMPANIES THAT PROVIDE SERVICES TO THIRD PARTIES IN THE FACE OF ENVIRONMENTAL HEALTH / WORK ENVIRONMENT}

RENATA MARQUES FERREIRA Pós-Doutora pela Universidade de São Paulo (Escola Politécnica-USP) e Doutora em Direito das Relações Sociais (sub área de Direitos Difusos e Coletivos-Direito Ambiental) pela Pontifícia Universidade Católica de São Paulo. Mestre em Direito das Relações Sociais (sub área de Direitos Difusos e Coletivos-Direito Ambiental Tributário) pela Pontifícia Universidade Católica de São Paulo. Professora convidada da Escola Superior de Advocacia da Ordem dos Advogados do Brasil - Seção de São Paulo (ESA-OAB/SP).

\section{CELSO ANTONIO PACHECO FIORILLO}

Doutor e Mestre em Direito das Relações Sociais.Director Académico do Congresso de Derecho Ambiental Contemporáneo España/Brasil-Universidade de Salamanca(ESPANHA) e Miembro del Grupo de Estudios Procesales de la Universidad de Salamanca-Grupo de Investigación Reconocido IUDICIUM(ESPANHA).Professor convidado visitante da Escola Superior de Tecnologia do Instituto Politécnico de Tomar(PORTUGAL) e Professor Visitante/Pesquisador da Facoltà di Giurisprudenza della Seconda Università Degli Studi di Napoli(ITALIA).Professor Permanente do Programa de Mestrado em Direito da UNINOVE-SP(BRASIL). Professor convidado do Curso de Especialização em Engenharia Sanitária Ambiental da Universidade Mackenzie.Professor da Escola Superior da Magistratura Federal do RS.Elaborador/coordenador/professor do Curso de Pós Graduação em Direito Ambiental da Escola Paulista da MagistraturaEPM.Professor MBA Direito Empresarial/FUNDACE-USP. 


\section{RESUMO}

A legalidade da contratação de serviços de terceiros para execução de atividades fim das empresas, conforme interpretação realizada em agosto de 2018 pelo STF, em nada altera o regime constitucional da chamada responsabilidade civil objetiva de referidas atividades econômicas no plano do direcionamento estabelecido pelos próprios princípios gerais da atividade econômica descritos em nossa Lei Maior (TÍTULO VII - Da Ordem Econômica e Financeira - CAPÍTULO I - DOS PRINCÍPIOS GERAIS DA ATIVIDADE ECONÔMICA).Destarte, dentre referidos princípios, merece destaque 0 da defesa do meio ambiente (Art.170, VI da CF), cujo conteúdo constitucional indicado no Art.225 da CF, aponta de forma explicita a existência da responsabilidade constitucional ambiental em face da tutela jurídica da saúde ambiental/ meio ambiente do trabalho no âmbito da relação jurídica ambiental previsra em nossa Carta Magna.

PALAVRAS-CHAVE: Terceirização; Bens Ambientais; Responsabilidade Ambiental das Empresas; Saúde Ambiental; Meio Ambiente do Trabalho.

\section{ABSTRACT}

The legality of the contracting of third party services to carry out business activities, as interpreted in August 2018 by the STF, does not alter the constitutional regime of socalled objective civil liability of said economic activities in the direction plan established by the general principles of economic activity described in our Major Law (TITLE VII ECONOMIC AND FINANCIAL ORDER - CHAPTER I - GENERAL PRINCIPLES OF ECONOMIC ACTIVITY). Among these principles, the defense of the environment deserves special mention (Art.170, VI CF), whose constitutional content indicated in Art.225 of the CF, explicitly points out the existence of constitutional environmental responsibility in the face of legal protection of environmental health / work environment within the ambit of the environmental legal relationship foreseen in our Magna Carta.

KEYWORDS: Outsourcing; Environmental Goods; Environmental Responsibility of Companies; Environmental health; Work Environment. 


\section{INTRODUÇÃO}

Aprovada em março de 2017, quando entrou em vigor a Lei $\mathrm{n} . \stackrel{0}{ }$ 13.429/2017(que dispõe sobre o trabalho temporário e sobre as relações trabalhistas em empresas que prestam serviços a terceiros) e acolhida pela denominada reforma trabalhista (lei n. ${ }^{-13.467 / 2017}$ que alterou artigos da Consolidação das Leis do Trabalho-CLT) que a teria "aperfeiçoado" ao estabelecer em face dos dois polos da relação laboral quanto à natureza do trabalho terceirizado que "considera-se prestação de serviços a terceiros a transferência feita pela contratante da execução de quaisquer de suas atividades, inclusive sua atividade principal, à pessoa jurídica de direito privado prestadora de serviços que possua capacidade econômica compatível com a sua execução" (artigo 2. da Lei n.ำ13.467/2017), a matéria teve sua constitucionalidade tratada pelo plenário Supremo Tribunal Federal em 30/08/2018, a saber, ao julgar a Arguição de Descumprimento de Preceito Fundamental (ADPF) 324 e o Recurso Extraordinário (RE) 958252¹ , com repercussão geral reconhecida, o Supremo Tribunal Federal decidiu em 30/08/2018 que a terceirização das chamadas atividades-fim de uma empresa não viola a Constituição.

Destarte ao adotar o entendimento de que nada existiria de ilegal na contratação de serviços de terceiros para execução de atividades fim das empresas em face de uma interpretação no sentido de que a Constituição não faz distinção entre atividade-meio e atividade-fim, o STF ressalvou, todavia, que as empresas contratantes são responsáveis, subsidiariamente, pelas dívidas trabalhistas das empresas contratadas nos casos em que estas demonstrarem falta de recursos para arcar com suas obrigações contratuais.

\footnotetext{
1 Trata-se de Recurso extraordinário em que se discutiu, à luz dos arts. 2ํㅗ는, II, XXXVI, LIV e LV e 97 da Constituição federal, a licitude da contratação de mão-de-obra terceirizada, para prestação de serviços relacionados com a atividade-fim da empresa tomadora de serviços, haja vista o que dispõe a Súmula 331 do Tribunal Superior do Trabalho e o alcance da liberdade de contratar na esfera trabalhista. A tese de repercussão geral aprovada no $R E$ foi a seguinte:
}

\begin{tabular}{|c|c|c|}
\hline Tema & Leading Case & Tese \\
\hline 725 & RE 958252 & $\begin{array}{l}\text { É lícita a terceirização ou qualquer outra forma de divisão do trabalho } \\
\text { entre pessoas jurídicas distintas, independentemente do objeto social das } \\
\text { empresas envolvidas, mantida a responsabilidade subsidiária da } \\
\text { empresa contratante. }\end{array}$ \\
\hline
\end{tabular}


Todavia nada indicou o Supremo Tribunal Federal a respeito das responsabilidades/ deveres de referidas empresas no que se refere à saúde ambiental dos trabalhadores particularmente em face das superiores normas constitucionais vinculadas ao meio ambiente do trabalho.

Cabe, pois analisar o tema de forma sistemática visando particularmente estabelecer em que medida a pessoa jurídica de direito privado prestadora de serviços a terceiros continua submetida às superiores determinações de nosso direito ambiental constitucional.

Senão vejamos.

\section{EMPRESAS QUE PRESTAM SERVIÇOS A TERCEIROS EM FACE DAS ATIVIDADES PREVISTAS NO ÂMBITO DA ORDEM ECONÔMICA CONSTITUCIONAL: SEUS REFLEXOS NO DIREITO AMBIENTAL CONSTITUCIONAL CONFORME ORIENTAÇÃO ESTABELECIDA PELA ADI 3540.}

Ao assegurar a todos o livre exercício de qualquer atividade econômica, independentemente de autorização de órgãos públicos, salvo nos casos previstos em lei, (parágrafo único do art. 170 da CF) nossa Constituição Federal destacou de forma importante a necessidade de se interpretar no plano normativo o significado de referido conceito de atividade em face de seus evidentes reflexos em toda a ordem econômica constitucional particularmente em decorrência do direcionamento estabelecido pelos próprios princípios gerais da atividade econômica (TÍTULO VII Da Ordem Econômica e Financeira - CAPÍTULO I - DOS PRINCÍPIOS GERAIS DA ATIVIDADE ECONÔMICA). Não se trata de pura e simplesmente compreender a atividade em face tão somente da economia, a saber, dentro do termo economia, lembrando Antonio Dias Leite, como o "quadro físico e institucional dentro do qual se realizam as atividades de produção de bens e serviços requeridos pela sociedade, bem como sua evolução no tempo", mas de compreender de que forma "as atividades de produção de bens e serviços requeridos pela sociedade", incluídas evidentemente as empresas que prestam serviços a terceiros, tem seu balizamento fixado pela Constituição Federal. 
Trata-se, pois de verificar o que significa atividade no contexto econômico normativo constitucional lembrando, de forma evidentemente menos ampla, dentro de análise doutrinária jurídica e em contexto infraconstitucional, ser a atividade "conceito básico de direito comercial, fenômeno essencialmente humano (Bonfante, Lezioni di storia del commercio). E hoje se pode afirmar que é conceito básico de direito empresarial. A empresa se realiza pela atividade, como o sujeito se realiza por seus atos. Tanto $\mathrm{o}$ ato quanto a atividade se exteriorizam por meio de negócios jurídicos, de tal sorte que se afirma que o contrato é o núcleo básico da atividade empresarial (Bulgarelli, Contratos mercantis,p.25)" .

Todavia, atribuindo ao termo posição juridicamente superior a Constituição Federal passou a entender a partir de 1988 ser a atividade no plano normativo econômico descrito na Lei Maior conceito bem mais amplo abarcando não só as comerciais e empresariais mas também e particularmente indicando a atividade em face da defesa do meio ambiente o que significa compreender a matéria ora desenvolvida ,como salienta Celso Fiorillo (2019), em face do conceito amplo e abrangente das noções de meio ambiente natural, de meio ambiente cultural , de meio ambiente artificial (espaço urbano) e de meio ambiente laboral.

Com efeito.

Entendida como "qualidade; faculdade ou possibilidade de agir, de se mover, de fazer, empreender coisas; exercício dessa faculdade, ação" em face do que se admite ser ativo ("que exerce ação, que age, que tem a faculdade de agir") o termo atividade também pode ser perfeitamente explicado no âmbito da economia(atividade econômica) como a faculdade de empreender coisas o que facilita evidentemente seu entendimento no contexto da ordem econômica constitucional com evidentes reflexos no direito ambiental constitucional, ou seja, a livre iniciativa passa a atuar em absoluta sintonia com os princípios fundamentais do direito ambiental constitucional.

Assim, conforme inclusive já definido pelo Supremo Tribunal Federal se:

[...] é certo que a ordem econômica na Constituição de 1988 define opção por um sistema no qual joga um papel primordial a livre iniciativa. Essa circunstância não legitima, no entanto, a assertiva de que o Estado só intervirá na economia em situações excepcionais. Mais do que simples instrumento de governo, a nossa Constituição enuncia diretrizes, programas e fins a serem realizados pelo Estado e pela sociedade. Postula um plano de ação global normativo para o Estado e para a sociedade, informado pelos preceitos veiculados pelos seus arts. 1으, $3^{\circ}$ e 170 . A livre iniciativa é expressão de liberdade titulada não apenas pela empresa, mas também pelo 
trabalho. Por isso a Constituição, ao contemplá-la, cogita também da "iniciativa do Estado".

Não a privilegia, portanto, como bem pertinente apenas à empresa. Se de um lado a Constituição assegura a livre iniciativa, de outro determina ao Estado a adoção de todas as providências tendentes a garantir o efetivo exercício do direito à educação, à cultura e ao desporto (arts. 23, V; 205; 208; 215; e 217, § 3ํ, da Constituição). Na composição entre esses princípios e regras, há de ser preservado o interesse da coletividade, interesse público primário. O direito ao acesso à cultura, ao esporte e ao lazer são meios de complementar a formação dos estudantes.

Assim, no plano superior constitucional em vigor (princípio fundamental), a livre iniciativa (Art. $1^{\circ}, \mathrm{IV}$ da CF) como "princípio do liberalismo econômico que defende a total liberdade do indivíduo para escolher e orientar sua ação econômica, independentemente da ação de grupos sociais ou do Estado" implicando conforme explicação de Paulo Sandroni (1999) em "total garantia da propriedade privada, o direito de o empresário investir seu capital no ramo que considerar mais favorável e fabricar e distribuir os bens produzidos em sua empresa da forma que achar mais conveniente à realização dos lucros" ,deixa de ser observada em face de sua interpretação inicial e passa a ser admitida em contexto de evidente equilíbrio.

Trata-se por via de consequência, como observa Celso Fiorillo (2018), de se verificar que a ordem econômica estabelecida no plano normativo constitucional, fundada na valorização do trabalho humano e na livre iniciativa, tem por fim assegurar a todos existência digna, conforme os ditames da justiça social, observados alguns princípios indicados nos incisos do Art.170 sendo certo que dentre os referidos princípios, está exatamente o da defesa do meio ambiente (Art.170, VI da CF), cujo conteúdo constitucional está descrito no Art.225 da CF, inclusive mediante tratamento diferenciado conforme o impacto ambiental (Art.225, parágrafo 1ํㅡㄴ IV) dos produtos e serviços e de seus processos de elaboração e prestação.

Como lembra referido autor, a defesa do meio ambiente embora adote como causa primária no plano normativo os valores sociais do trabalho e da livre iniciativa (Art. $1^{\circ}$, IV) necessita respeitar a dignidade da pessoa humana como superior fundamento constitucional (Art. $1^{\circ}$, III).

Adotando referida visão doutrinária o Supremo Tribunal Federal teve a oportunidade de fixar a adequada interpretação da matéria conforme decidiu na 
conhecida ADI 3540 cuja ementa, por sua evidente importância para o tema ora analisado merece ser transcrita, a saber:

"A atividade econômica não pode ser exercida em desarmonia com os princípios destinados a tornar efetiva a proteção ao meio ambiente. A incolumidade do meio ambiente não pode ser comprometida por interesses empresariais nem ficar dependente de motivações de índole meramente econômica, ainda mais se se tiver presente que a atividade econômica, considerada a disciplina constitucional que a rege, está subordinada, entre outros princípios gerais, àquele que privilegia a "defesa do meio ambiente" (CF, art. 170, VI), que traduz conceito amplo e abrangente das noções de meio ambiente natural, de meio ambiente cultural, de meio ambiente artificial (espaço urbano) e de meio ambiente laboral. Doutrina. Os instrumentos jurídicos de caráter legal e de natureza constitucional objetivam viabilizar a tutela efetiva do meio ambiente, para que não se alterem as propriedades e os atributos que Ihe são inerentes, o que provocaria inaceitável comprometimento da saúde, segurança, cultura, trabalho e bem-estar da população, além de causar graves danos ecológicos ao patrimônio ambiental, considerado este em seu aspecto físico ou natural. [ADI 3.540 MC, rel. min. Celso de Mello, j. 1-9-2005, P, DJ de 3-2-2006.]".

Destarte ao assegurar a todos o livre exercício de qualquer atividade econômica, nossa Constituição Federal condiciona o exercício de referida atividade no plano normativo à defesa do meio ambiente natural, do meio ambiente cultural, do meio ambiente artificial (espaço urbano) e do meio ambiente laboral tudo em face dos princípios do direito ambiental constitucional na forma de suas respectivas tutelas jurídicas constitucionais. As empresas que prestam serviços a terceiros se submetem, pois às determinações constitucionais antes referidas.

\section{EMPRESAS QUE PRESTAM SERVIÇOS A TERCEIROS COMO ATIVIDADE PREVISTA NO ÂMBITO DO ART.225 DA CONSTITUIÇÃO FEDERAL E SEUS REFLEXOS NO DIREITO AMBIENTAL CONSTITUCIONAL}

Conforme verificamos, além de atribuir à expressão "atividade" posição juridicamente superior com inúmeros reflexos no plano da Carta Magna, a Constituição Federal passou a entender a partir de 1988 ser a atividade fator 
fundamental relacionado particularmente à própria ordem econômica e financeira constitucional em vigor vinculando a referida expressão também aos princípios gerais da atividade econômica.

Por outro lado entendeu também a Carta Magna ser adequado estabelecer de forma explicita no plano da tutela jurídica constitucional a expressão "atividade" vinculada ao regime jurídico dos bens ambientais ( Art. 225, § 1ํㅡㄹ IV e parágrafo 30 ), o que nos possibilita afirmar também ser a atividade ,conforme estabelece Celso Fiorillo (2019), um conceito fundamental relacionado ao direito ambiental constitucional brasileiro sendo certo que o $\S 3^{\circ}$,do Art.225 da Constituição Federal estabelece que as atividades consideradas lesivas ao meio ambiente sujeitarão os infratores, pessoas físicas ou jurídicas, a sanções penais e administrativas, independentemente da obrigação de reparar os danos causados.

Quais são as atividades consideradas juridicamente lesivas ao meio ambiente?

São as chamadas atividades poluidoras, vale dizer, aquelas alterações adversas das características do meio ambiente (Patrimônio Genético, Meio Ambiental Cultural, Meio Ambiente Digital, Meio Ambiente Artificial/Cidades, Saúde Ambiental/Meio Ambiente do Trabalho e Meio Ambiente Natural) resultantes de atividades que direta ou indiretamente afetem no plano constitucional os bens ambientais e no plano infraconstitucional a) prejudiquem a saúde, a segurança e o bem-estar da população; b) criem condições adversas às atividades sociais e econômicas; c) afetem desfavoravelmente a biota; d) afetem as condições estéticas ou sanitárias do meio ambiente; e e) lancem matérias ou energia em desacordo com os padrões ambientais estabelecidos (Art.30,inciso III letras "a", "b", "c", "d" e "e" da lei 6938/81).

Destarte as Empresas que prestam serviços a terceiros nas hipóteses em que atuam como atividade poluidora estão sujeitas ao direito ambiental constitucional submetendo se à responsabilidade constitucional de reparar danos causados. 


\section{ATIVIDADES CONSIDERADAS LESIVAS AO MEIO AMBIENTE SUJEITANDO OS INFRATORES, INCLUSIVE EMPRESAS QUE PRESTAM SERVIÇOS A TERCEIROS, À OBRIGAÇÃO DE REPARAR OS DANOS CAUSADOS}

Ao verificar o conteúdo do art. 225, § 3ํ, da Constituição Federal podemos efetivamente observar a existência de uma tríplice responsabilidade do poluidor em face de atividades consideradas lesivas ao meio ambiente (tanto pessoa física como jurídica): a sanção penal, por conta da chamada responsabilidade penal (ou responsabilidade criminal), a sanção administrativa, em decorrência da denominada responsabilidade administrativa, e ainda a sanção que, como adverte Celso Fiorillo (2018) "didaticamente poderíamos denominar civil, em razão da responsabilidade vinculada à obrigação de reparar danos causados ao meio ambiente" .

Tratar de responsabilidade civil no âmbito do direito ambiental constitucional significa enfrentar o tema dentro da denominada teoria da responsabilidade civil sendo certo que, como destaca Celso Fiorillo (2019), "dentro da teoria da responsabilidade civil, não há como falar em dever de indenizar sem a ocorrência do dano".

Dessa feita, na lição do referido autor o termo dano constitui um dos alicerces essenciais da responsabilidade civil, de modo que se faz imprescindível conceituá-lo.

Primeiramente, adverte Celso Fiorillo (2019):

[...] é importante ressaltar que inexiste, a nosso ver, relação indissociável entre a responsabilidade civil e o ato ilícito, de forma que haverá dano mesmo que este não derive de um ato ilícito. Observemos a seguinte situação: suponhamos que uma determinada empresa $X$ emita efluentes dentro do padrão ambiental estabelecido pelo órgão competente. Admitindo que a fauna ictiológica seja contaminada pela referida descarga de dejetos, há, indiscutivelmente, apesar de a empresa ter agido licitamente, o dever de indenizar, pois, em face da responsabilidade objetiva, verifica-se apenas 0 dano (contaminação da biota) com o nexo de causalidade (oriundo da atividade da empresa), para que daí decorra o dever de indenizar.Dessa forma, o conceito que se coaduna com o aqui exposto é o de que dano é a lesão a um bem jurídico. Ocorrendo, pois, lesão a um bem ambiental, resultante de atividade praticada por pessoa física ou jurídica, pública ou privada, que direta ou indiretamente seja responsável pelo dano, inclusive as Empresas que prestam serviços a terceiros, não só há a caracterização deste como a identificação do poluidor, aquele que terá o dever de indenizar. 


\section{ATIVIDADES CONSIDERADAS LESIVAS AO MEIO AMBIENTE DO TRABALHO/SAÚDE AMBIENTAL SUJEITANDO OS INFRATORES, INCLUSIVE EMPRESAS QUE PRESTAM SERVIÇOS A TERCEIROS, À OBRIGAÇÃO DE REPARAR OS DANOS CAUSADOS}

\subsection{NATUREZA JURÍDICA DA SAÚDE COMO BEM AMBIENTAL E SEUS REFLEXOS NO SISTEMA NORMATIVO CONSTITUCIONAL}

A doutrina italiana, que desenvolveu importante contribuição no que se refere à estruturação jurídica dos bens ambientais de forma geral ${ }^{2}$, ao desenvolver analise tendente à composição unitária dos componentes ambientais isoladamente tomados em um único bem jurídico, moveu-se inicialmente sob a intenção de reencontrar tal elemento de ligação na posição do sujeito, individual ou coletivo, que possui interesse na tutela do ambiente.

$\mathrm{Na}$ oportunidade em que os debates se desenvolveram, a posição subjetiva que apareceu tutelável relativamente à poluição foi aquela do direito de propriedade sendo certo que pioneiramente tentou se estabelecer outra reconstrução unitária do meio ambiente com referencia a diferentes posições subjetivas individuais e particularmente a um direito personalíssimo: o direito à saúde, na sua configuração de direito ao ambiente saudável.

O fundamento de tal direito foi reconhecido no art. 32 da Constituição ${ }^{3}$ e, embora recebendo algumas críticas, como a de Gianpietro (1988) ao aduzir que "o direito à saúde não surge em todo o caso em condições de assegurar a unidade do meio ambiente no sentido jurídico" obteve uma acolhida favorável, principalmente na jurisprudência italiana ${ }^{4}$.

Todavia diante da efetiva dificuldade de se estabelecer no âmbito doutrinário um critério unívoco a respeito do bem ambiental, particularmente em decorrência da existência de várias teorias do ambiente como bem jurídico (teoria da especificação do elemento unificador no direito subjetivo individual, teoria do ambiente como objeto

\footnotetext{
2 Vide de forma detalhada FIORILLO, 2000.

3 "A República tutela a saúde como direito fundamental do indivíduo e interesse da coletividade e garante tratamento gratuito aos indigentes. Ninguém pode ser obrigado a um determinado tratamento a não ser por posição legal. A lei não pode em nenhum caso violar os limites impostos ao respeito à pessoa humana."

${ }^{4}$ Cass. SS. UU. 6-10-1979, Jurisprudência Italiana, 1980.
} 
unitário de interesses difusos, teoria do ambiente como objeto unitário de planejamento urbano, teoria do ambiente como bem público e, portanto, do erário, na jurisprudência da Corte de Contas italiana, e a tese da uniformidade do meio ambiente no que tange ao dano ambiental, a teor do art. 18 da Lei italiana n. 349, de 8 de julho de 1986) o tema não ficou bem consolidado.

No Brasil, todavia a Constituição Federal de 1988, de forma paradigmática, não só definiu a natureza jurídica do bem ambiental como harmonizou explicitamente a matéria em face da saúde ${ }^{5}$.

Com efeito.

$\mathrm{O}$ art. 225 da Constituição Federal estabelece que o meio ambiente ecologicamente equilibrado está estruturado juridicamente como bem essencial à sadia qualidade de vida sendo de uso comum do povo.

Destarte, ao enunciá-lo como essencial à qualidade de vida, o dispositivo recepcionou o conceito de meio ambiente estabelecido na Política Nacional do Meio Ambiente (Lei n. 6.938/81), qual seja, "o conjunto de condições, leis, influências e interações de ordem física, química e biológica, que permite, abriga e rege a vida em todas as suas formas" (art. $3 \stackrel{0}{\circ}, 1$ ), dentro de uma concepção, que determina uma estreita e correta ligação entre a tutela jurídica do meio ambiente e a defesa da dignidade da pessoa humana dando particular relevo à incolumidade físico-psíquica da pessoa humana.

A expressão "sadia qualidade de vida", explicitada no art.225 da Lei Maior de nosso País, associa, pois o direito à vida ao direito à saúde, na exata medida do que sustentam Carlo Malinconico (1991) em sua obra clássica dentro de uma concepção destinada a impedir que o meio ambiente, como sustentam Celso Fiorillo e Renata Ferreira (2018): "[...] viesse a ser apenas uma questão de sobrevivência, mas, efetivamente, "algo mais" dentro de um parâmetro, vinculando o direito à vida em face de uma tutela à saúde com padrões de qualidade e dignidade.

Nota-se, portanto, que, em face da noção jurídica de meio ambiente estabelecida pelo Supremo Tribunal Federal(ADIN 3540) e mesmo em decorrência do desenvolvimento doutrinário especializado articulado na análise do meio ambiente em face do patrimônio genético, do meio ambiente cultural, do meio ambiente digital, do

5 Vide de forma detalhada FIORILLO; FERREIRA, 2018. 
meio ambiente artificial, do meio ambiente do trabalho e do meio ambiente natural, as visões anteriormente indicadas não possuem outra função senão delimitar seu espectro, a que se está referindo dentro de uma aparente dissociação vinculada a um sentido meramente expletivo, na medida em que o conceito de meio ambiente, em face do desenvolvimento doutrinário especializado, está indissociavelmente associado ao direito à vida.

Exatamente nesse sentido a lição de Giannini (1973) quando afirma que o meio ambiente não pode ter um tratamento fragmentalizado ou isolado em setores estanques, ou mesmo as ideias de Prieur (2016), dentro de uma concepção em que o ambiente seria:

[...] a expressão das alterações e das relações dos seres vivos, incluindo o homem, entre eles e o seu meio, sem surpreender que o direito do ambiente seja, assim, um direito de interações que tende a penetrar em todos os setores do direito para aí introduzir a ideia de ambiente.

Com fundamento nessas considerações preliminares acerca do direito ao meio ambiente, podemos identificar a natureza jurídica do chamado bem ambiental.

Foi principalmente a partir da segunda metade do século XX, em decorrência do surgimento dos fenômenos de massa, quando se observou a formação da denominada "sociedade de massa", que os bens de natureza difusa passaram a ser objeto de maior preocupação do aplicador do direito e mesmo dos cientistas e legisladores como um todo.

Observados pela doutrina italiana, principalmente a partir da visão de Cappelletti (1975) do abismo criado entre o "público e o privado", preenchido pelos direitos metaindividuais, emergiram os denominados bens de natureza difusa como uma alternativa essencial em face da dogmática jurídica estabelecida até o século XX.

No Brasil, o desenvolvimento doutrinário antes referido acabou por gerar reflexos na Constituição Federal de 1988 fixando orientação para a realidade do século XXI, tendo como pressuposto a moderna sociedade de massas dentro de um contexto de tutela de direitos e interesses adaptados às necessidades, principalmente metaindividuais e objetivamente ligados à dignidade da pessoa humana.

Sob esse enfoque, surgiu a Lei Federal n. 8.078, de 1990, que, além de estabelecer nova concepção, vinculada aos direitos das relações de consumo, criou, a partir da orientação estabelecida pela Carta Magna de 1988, a estrutura 
infraconstitucional que fundamenta a natureza jurídica de um novo bem, que não é público e não é privado: os bens ambientais de natureza metaindividual."

Criado, todavia no plano mais importante do sistema jurídico brasileiro, como já aludido, os bens ambientais passaram a ter clara definição legal no plano superior e infraconstitucional, com evidentes reflexos, conforme já tivemos a oportunidade de aduzir anteriormente, na própria intepretação sistemática de toda a Carta Magna, configurando nova realidade para o intérprete do direito positivo brasileiro.

Aludido bem, definido em regra como transindividual, tendo como titulares pessoas indeterminadas e ligadas por circunstâncias de fato (art. 81, parágrafo único, I, da Lei n. 8.078/90), pressupõe, sob a ótica normativa, a existência de um bem "de natureza indivisível", ou seja, um bem que "não pode ser fracionado por sua natureza, por determinação de lei ou por vontade das partes" conforme nos lembra Diniz (1998 ;p.393).

Por outro lado, no superior plano constitucional, o art. 225 de nossa Lei Maior, ao estabelecer a existência jurídica de um bem essencial à sadia qualidade de vida de uso comum do povo, entendeu por bem estruturar nova realidade jurídica disciplinando bem que, não é público nem, muito menos, particular rompendo o dogma dos "dois grandes interesses" que sempre formaram a interpretação do sistema normativo pátrio em face da divisão em direito público(bens públicos) e direito particular(bens particulares).

Assim, não se reportando a uma pessoa individualmente concebida e muito menos ao Estado/pessoas jurídicas de direito público interno e sim a uma coletividade de pessoas indefinidas, o que demarca um critério transindividual, em que não se determinam, de forma rigorosa, as pessoas titulares desse direito, o art. 225 da Constituição Federal estabeleceu por via de consequência a existência de uma norma vinculada ao meio ambiente ecologicamente equilibrado, reafirmando, ainda, que todos são titulares/usuários do referido direito.

O bem ambiental estabelecido pela Constituição Federal de 1988 é, portanto, um bem que tem como característica constitucional mais relevante ser essencial à sadia qualidade de vida da pessoa humana, sendo ontologicamente de uso comum do povo, podendo ser desfrutado/usado por toda e qualquer pessoa dentro dos limites constitucionais. 
Note-se ainda, conforme já tivemos oportunidade de desenvolver anteriormente, que a doutrina italiana já insinuava que não é somente o traço de titularidade que diferencia um bem ambiental dos outros bens existentes em nosso ordenamento jurídico. Sustenta a distinção num critério objetivo, que reside na indivisibilidade do bem, objeto sobre o qual resultará o interesse respectivo cabendo para tanto relembrar o conteúdo da Lei Federal n. 8.078/90.

Entre bem ambiental e bem público, contudo, haveria tênue liame, que se reforçaria diante da aplicação do critério subjetivo para a distinção de cada um deles.

Com efeito.

A distinção entre bem público e bem ambiental reclamaria ainda a análise não só do art. 66 do Código Civil de 1916 como de sua "cópia" no Código Civil de 2002 (art. 99). O legislador de 1916 atribuiu ao que chamamos atualmente de bem ambiental a característica de espécie de bem público; o legislador civil de 2002, como dissemos, transportou o conceito do final do século XIX/início do século XX pura e simplesmente para o século $X X I$... resta evidente que os conceitos do subsistema civil não guardam compatibilidade com o conceito descrito no art. 225 da Constituição Federal.

A matéria, todavia foi satisfatoriamente enfrentada a partir do ano de 2010 quando o Supremo Tribunal Federal, acolhendo nossa interpretação, não só reconheceu que são distintos os bens jurídicos ambientais e os bens jurídicos públicos como indicou a necessidade fundamental de reforçar a tutela do bem jurídico ambiental conforme podemos constatar, a saber:

Os arts. 2 을 da Lei $8.176 / 91$ e 55 da Lei $9.605 / 98$ tutelam bens jurídicos distintos: o primeiro visa a resguardar o patrimônio da União; o segundo protege o meio ambiente (grifos nossos). Daí a improcedência da alegação de que o art. 55 da Lei 9.605/98 revogou o art. 2o da Lei 8.176/91" (BRASIL, 2010).

HABEAS CORPUS. PENAL. PROCESSUAL PENAL. EXTRAÇÃO DE OURO. INTERESSE PATRIMONIAL DA UNIÃO. ART. 2음 DA LEI N. 8.176/1991. CRIME CONTRA O MEIO AMBIENTE. ART. 55 DA LEI N. 9.605/1998. BENS JURÍDICOS DISTINTOS. CONCURSO FORMAL. INEXISTÊNCIA DE CONFLITO APARENTE DE NORMAS. AFASTAMENTO DO PRINCÍPIO DA ESPECIALIDADE. INCOMPETÊNCIA DO JUIZADO ESPECIAL FEDERAL. 1. Como se trata, na espécie vertente, de concurso formal entre os delitos do art. $2 \stackrel{\circ}{\underline{o}}$ da Lei n. 8.176/1991 e do art. 55 da Lei $n$. 9.605/1998, que dispõem sobre bens jurídicos distintos (patrimônio da União e meio ambiente, respectivamente), não há falar em aplicação do princípio da especialidade para fixar a competência do Juizado Especial 
Federal. 2. Ordem denegada" (BRASIL, 2012).

\begin{abstract}
O art. 225, § 3ำ da CF não condiciona a responsabilização penal da pessoa jurídica por crimes ambientais à simultânea persecução penal da pessoa física em tese responsável no âmbito da empresa. A norma constitucional não impõe a necessária dupla imputação. As organizações corporativas complexas da atualidade se caracterizam pela descentralização e distribuição de atribuições e responsabilidades, sendo inerentes, a esta realidade, dificuldades para imputar o fato ilícito a uma pessoa concreta. Condicionar a aplicação do art. 225, § 3 , da Carta Política a uma concreta imputação também a pessoa física implica indevida restrição da norma constitucional, expressa a intenção do constituinte originário não apenas de ampliar o alcance das sanções penais, mas também de evitar a impunidade pelos crimes ambientais frente às imensas dificuldades de individualização dos responsáveis internamente às corporações, além de reforçar a tutela do bem jurídico ambiental (grifos nossos). A identificação dos setores e agentes internos da empresa determinantes da produção do fato ilícito tem relevância e deve ser buscada no caso concreto como forma de esclarecer se esses indivíduos ou órgãos atuaram ou deliberaram no exercício regular de suas atribuições internas à sociedade, e ainda para verificar se a atuação se deu no interesse ou em benefício da entidade coletiva. Tal esclarecimento, relevante para fins de imputar determinado delito à pessoa jurídica, não se confunde, todavia, com subordinar a responsabilização da pessoa jurídica à responsabilização conjunta e cumulativa das pessoas físicas envolvidas. Em não raras oportunidades, as responsabilidades internas pelo fato estarão diluídas ou parcializadas de tal modo que não permitirão a imputação de responsabilidade penal individual. (BRASIL, 2014).
\end{abstract}

Destarte, resta evidente a natureza jurídica da saúde como bem ambiental gerando importantes reflexos no sistema normativo constitucional como, por exemplo, a integral aplicação de todos os princípios constitucionais do direito ambiental em face da saúde e demais regras ambientais constitucionais pertinentes.

\author{
5.2 A SAÚDE COMO DIREITO CONSTITUCIONAL INTEGRANTE DO PISO VITAL \\ MÍNIMO (ART.6음 DA CF) E SEU ENQUADRAMENTO NO ÂMBITO DO CONCEITO \\ PLURAL DE MEIO AMBIENTE ACOLHIDO PELO SUPREMO TRIBUNAL FEDERAL
} (ADI 3540)

Reportando-se aos destinatários da norma constitucional, que são os brasileiros e estrangeiros residentes no País (Art.5ํ da CF), e claramente vinculada à concepção de ser "essencial à sadia qualidade de vida" descrita no caput do Art.225, a saúde, como bem ambiental, tem como objetivo imediato a tutela jurídica da dignidade do ser humano e, de forma mediata, outros valores que também venham a ser estabelecidos na Constituição Federal. 
Por conta dessa visão, devemos compreender o que seja essencial, adotando um padrão mínimo de interpretação ao art. 225 em face dos dizeres do art. 1으, combinado com o art. 6으 da Constituição Federal, que fixa o piso vital mínimo. Com efeito, um dos princípios fundamentais da República Federativa do Brasil é o da dignidade da pessoa humana, e, para que uma pessoa tenha a tutela mínima de direitos constitucionais adaptada ao direito ambiental deve possuir uma vida não só sob o ponto de vista fisiológico, mas sobretudo concebida por valores outros, como os culturais, que são fundamentais para que ela possa sobreviver, em conformidade com a nossa estrutura constitucional

Destarte, embora unitário, o conceito de meio ambiente, porquanto todo este é regido por inúmeros princípios, diretrizes e objetivos que compõem o direito ambiental constitucional, estabelecido pela doutrina e posteriormente acolhida pelo Supremo Tribunal Federal, em aspectos que o compõem, busca facilitar a identificação da atividade degradante e do bem imediatamente agredido. Não se pode perder de vista que o direito ambiental tem como objeto maior tutelar a vida saudável, de modo que a classificação apena identifica o aspecto do meio ambiente em que valores maiores foram aviltados.

Daí verificarmos a tutela jurídica da saúde ambiental enquadrada no conceito amplo e abrangente de meio ambiente estabelecido na conhecida ADI 3540, a saber:

\begin{abstract}
A atividade econômica não pode ser exercida em desarmonia com os princípios destinados a tornar efetiva a proteção ao meio ambiente. A incolumidade do meio ambiente não pode ser comprometida por interesses empresariais nem ficar dependente de motivações de índole meramente econômica, ainda mais se se tiver presente que a atividade econômica, considerada a disciplina constitucional que a rege, está subordinada, dentre outros princípios gerais, àquele que privilegia a 'defesa do meio ambiente' (CF, art. 170, VI), que traduz conceito amplo e abrangente das noções de meio ambiente natural, de meio ambiente cultural, de meio ambiente artificial (espaço urbano) e de meio ambiente laboral. Doutrina. Os instrumentos jurídicos de caráter legal e de natureza constitucional objetivam viabilizar a tutela efetiva do meio ambiente, para que não se alterem as propriedades e os atributos que lhe são inerentes, o que provocaria inaceitável comprometimento da saúde, segurança, cultura, trabalho e bem-estar da população, além de causar graves danos ecológicos ao patrimônio ambiental, considerado este em seu aspecto físico ou natural (BRASIL, 2006).
\end{abstract}


pelo Supremo Tribunal Federal (ADI 3540), a saúde ambiental tem seu balizamento jurídico estruturado pelo direito ambiental constitucional e evidentemente por seus princípios gerais e específicos.

\subsection{CONDUTAS E ATIVIDADES CONSIDERADAS LESIVAS À SAÚDE SUJEITANDO OS INFRATORES, PESSOAS FÍSICAS OU JURÍDICAS, À OBRIGAÇÃO DE REPARAR OS DANOS CAUSADOS: A CHAMADA RESPONSABILIDADE CIVIL OBJETIVA EM FACE DA LESÃO À SAÚDE}

Determina nossa Lei Maior que condutas e atividades consideradas lesivas à saúde, como bem ambiental que é, sujeitam os infratores, pessoas físicas ou jurídicas, à obrigação de reparar os danos causados (Art.225, § $3^{\circ}$ ).

Destarte a responsabilidade derivada de lesão à saúde, comporta em princípio as três modalidades de danos estabelecidas em nossa Lei Maior que serão observadas caso a caso em face das circunstancias objetivas das hipóteses em que possam ocorrer (art. 5으, $\mathrm{V}$ e $\mathrm{X}$ ), a saber:

1) DANO MATERIAL - também chamado no subsistema civil de dano patrimonial, consiste em uma lesão (prejuízo) que venha a afetar determinado interesse relativo aos bens materiais de qualquer brasileiro ou estrangeiro residente no País (pessoa física ou jurídica), de forma individual ou coletiva (com reflexos no campo individual e metaindividual), representada pela deterioração ou mesmo pela perda (parcial ou integral) de aludidos bens materiais (corpóreos);

2) $D A N O M O R A L^{6}$ - consiste em uma lesão que venha a ofender determinado interesse que não seja corpóreo de qualquer brasileiro e estrangeiro residente no País (pessoa física), de forma individual ou coletiva ${ }^{7}$ (com reflexos no campo individual e

\footnotetext{
${ }^{6}$ Para o Dicionário de psicologia Dorsh, "moral, do latim 'relativo aos costumes', é o conjunto das normas que determinam o comportamento e avaliação - consciência".

7 Conforme divulgado em junho de 2012 pela Coordenadoria de Editoria e Imprensa do Superior Tribunal de Justiça, a possibilidade de indenização por dano moral está prevista na Constituição Federal, em seu artigo 5 o, inciso V. O texto não restringe a violação à esfera individual, e mudanças históricas e legislativas têm levado a doutrina e a jurisprudência a entender que, quando são atingidos valores e interesses fundamentais de um grupo, não há como negar a essa coletividade a defesa do seu patrimônio imaterial. $O$ dano moral coletivo é a lesão na esfera moral de uma comunidade, isto é, a violação de valores coletivos, atingidos injustificadamente do ponto de vista jurídico. Essas ações podem tratar de dano ambiental (lesão ao equilíbrio ecológico, à qualidade de vida e à saúde da coletividade), desrespeito aos direitos do consumidor (por exemplo, por publicidade abusiva), danos ao patrimônio histórico e artístico, violação à honra de determinada comunidade
} 
metaindividual), constituída pela ofensa de valores imateriais da pessoa humana ${ }^{8}$ tutelados pela Constituição Federal, afetando fundamentalmente a denominada "paz interior" de referidas pessoas;

3) DANO À IMAGEM - consiste em uma lesão que venha a atingir determinado interesse vinculado à reprodução das pessoas humanas, de forma individual ou coletiva (com reflexos no campo individual e metaindividual), constituída pela ofensa de valores tutelados pela Carta Magna ligados às pessoas antes referidas e que de alguma forma afetem a representação da forma ou do aspecto de ser de qualquer brasileiro ou estrangeiro residente no País (pessoa física ou jurídica) ${ }^{9}$.

São legitimados passivos todos aqueles que, de alguma forma 10, 11, 12, 13 14, foram os causadores do dano ambiental, sendo certo que a responsabilidade dos

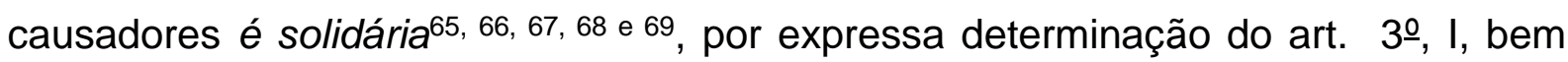
como pela Lei n. 6.938/81, que atribui a obrigação de indenizar o dano ambiental àqueles que, com a sua atividade, causaram dano"15 (grifo nosso) ${ }^{16}$ e 17

(negra, judaica, japonesa, indígena etc.) e até fraude a licitações. Vide: REsp 636.021, 971.844, 598.281, 821.891, 105.727-4, 118.007-8, 117.829-4, 122.175-6, 866.636.

${ }^{8} \mathrm{~A}$ ofensa é de valores imateriais da pessoa humana. Vide de forma detalhada FIORILLO, 2018.

9 Vide REsp 270.730, REsp 1.200.482, REsp 1.024.276, REsp 803.129, REsp 1.014.624, REsp 1.208.612, REsp 1.168.547, REsp 1.021.987, REsp 1.082.878, REsp 1.053.534, REsp 1.005.278 e HC 88448.

10 O STJ decidiu como indicado abaixo, a saber: "A tese recursal não prospera, tendo em vista que a responsabilidade por danos ambientais é solidária entre o poluidor direto e o indireto, o que permite que a ação seja ajuizada contra qualquer um deles, sendo facultativo o litisconsórcio. Precedentes do STJ" (Grifos nossos) (REsp 1.079.713-SC (2008/0169678-0), Rel. Min. Herman Benjamim, j. em 18-82009, v. u.).

${ }^{11}$ No que se refere ao princípio da solidariedade, vide entendimento do Supremo Tribunal Federal na ADI 1003-MC, Rel. Min. Celso de Mello, DJ, 10-9-1999.

${ }^{12}$ Reiteramos a importância do julgamento que condenou a União, por omissão no dever de fiscalizar, a recuperar área degradada em Santa Catarina, juntamente com as mineradoras que causaram dano ao ambiente por quase duas décadas. O STJ concluiu haver responsabilidade solidária entre 0 poder público e as empresas poluidoras, assim todos responderam pela reparação. Além disso, as ações coletivas de reparação de dano ambiental são imprescritíveis, isto é, podem ser propostas a qualquer tempo, pois não há um prazo limite definido em lei (REsp 647.493).

${ }_{13}$ Vide BRASIL, 2008.

${ }^{14}$ Conforme informado em 15-9-2009 pela Coordenadoria de Editoria e Imprensa "A responsabilidade por danos ao meio ambiente, além de objetiva, não exigindo a comprovação de culpa, é também solidária" (REsp 1.056.540).

${ }^{15}$ Rosa Maria Barreto Borrielo de Andrade Nery, Indenização do dano ambiental (responsabilidade civil e ação civil pública), tese de mestrado da PUCSP, 1993, p. 85.

$16 \mathrm{O}$ Superior Tribunal de Justiça vem adotando nosso posicionamento, reconhecendo inclusive que existe responsabilidade solidária entre o Poder Público e as empresas poluidoras, o que significa que todos respondem pela reparação (vide REsp 647.493, STJ, 2르 Turma, Rel. Min. João Otávio Noronha, maio de 2007).

${ }_{17}$ A ação civil pública ou coletiva que objetiva a responsabilização por dano ambiental pode ser proposta contra o poluidor, pessoa física ou jurídica, de direito público ou privado, responsável, direta ou indiretamente, por atividade causadora de degradação ambiental (art. 3o, IV, da Lei n. 6.898/91), todos coobrigados solidariamente à indenização, mediante litisconsórcio facultativo. A sua ausência 
Adotou por via de consequência nossa Lei Maior, no âmbito das relações jurídicas vinculadas aos bens ambientais, a chamada responsabilidade civil objetiva. Claro está que não se cuida efetivamente de uma responsabilidade propriamente civil, uma vez que a Constituição Federal estabelece regra própria em face de obrigação de reparar danos causados a bens ambientais, ou seja, o que existe no âmbito constitucional é uma verdadeira responsabilidade pela lesão aos bens ambientais.

Cabe lembrar que, anteriormente à Constituição Federal de 1988 e no plano infraconstitucional, a Lei da Política Nacional do Meio Ambiente (Lei n. 6.938/81) já previa a responsabilidade objetiva do poluidor no seu art. 14, $\S 1$ ‥ Com a promulgação da Lei Maior tal norma infraconstitucional foi recepcionada, tendo como fundamento de validade 0 art. 225, $\S 3$ o, porquanto este não estabeleceu qualquer critério ou elemento vinculado à culpa como determinante para o dever de reparar o dano causado ao meio ambiente. Consagrou-se, portanto, a responsabilidade objetiva em relação aos danos ambientais.

A adoção pela Constituição Federal do regime da responsabilidade objetiva implica a impossibilidade de alteração desse regime jurídico da responsabilidade chamada civil, em matéria ambiental, por qualquer lei infraconstitucional18.

\subsection{TUTELA JURÍDICA DA SAÚDE EM FACE DO MEIO AMBIENTE DO TRABALHO}

\subsubsection{O meio ambiente do trabalho}

Ratificando manifestação que há muitos anos Celso Fiorillo desenvolve ${ }^{19} \mathrm{a}$ Constituição Federal de 1988 dispensa ao meio ambiente do trabalho tutela imediata e mediata ${ }^{20}$.

Com efeito, prescreve o art. 200, VIII:

não acarreta a nulidade do processo. Precedentes citados: REsp 604.725-PR, DJ, 22-8-2005, e REsp 21.376-SP, DJ, 15-4-1996. REsp 884.150-MT, Rel. Min. Luiz Fux, julgado em 19-6-2008.

18 "AGRAVO REGIMENTAL NO RECURSO EXTRAORDINÁRIO. DIREITO AMBIENTAL. AÇÃO CIVIL PÚBLICA. RESPONSABILIDADE CIVIL OBJETIVA SOLIDÁRIA. ANÁLISE DE NORMAS INFRACONSTITUCIONAIS. OFENSA CONSTITUCIONAL INDIRETA. AGRAVO REGIMENTAL AO QUAL SE NEGA PROVIMENTO" (BRASIL, 2013).

${ }^{19}$ Vide Curso de Direito Ambiental Brasileiro desde sua primeira edição (2000). Editora Saraiva.

${ }^{20}$ Vide BRASIL, 2013 
"Art. 200. Ao sistema único de saúde compete, além de outras atribuições, nos termos da lei: [...] VIII - colaborar na proteção do meio ambiente, nele compreendido o do trabalho"21 e 22 .

Ainda 0 art. 7o, nos seus incisos XXII e XXIII, da Constituição Federal prescreve:

Art. $7 \underline{\underline{0}}$ São direitos dos trabalhadores urbanos e rurais, além de outros que visem à melhoria de sua condição social: [...] XXII - redução dos riscos inerentes ao trabalho, por meio de normas de saúde, higiene e segurança; XXIII - adicional de remuneração para as atividades penosas, insalubres ${ }^{23}$ ou perigosas, na forma da lei".

Esses dois dispositivos preveem a tutela imediata do meio ambiente do

trabalho. A mediata tem respaldo no caput do art. 225 da Constituição Federal.

${ }^{21}$ Vide BRASIL, 2012.

22 Vide STF, RE 214.001 AgR/SP, 2를 Turma, Min. Teori Zavascki, j. em 27-8-2013.

${ }^{23}$ Conforme noticiou o STF em 2 de agosto de 2010, "ao analisar um conjunto de 21 Mandados de Injunção sobre aposentadoria especial de servidores públicos, o Plenário do Supremo Tribunal Federal (STF) concedeu a ordem em todos os casos, garantindo o direito à aposentadoria especial, desde que a área administrativa responsável confirme o atendimento aos requisitos da lei da Previdência Social. Em todos os processos, a alegação é a mesma: os impetrantes afirmam trabalhar em situações

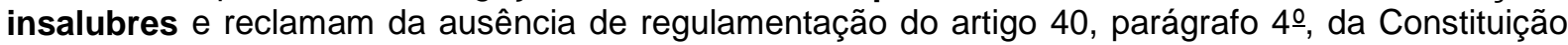
Federal, que trata do direito à aposentadoria especial dos servidores públicos.

O relator dos mandados de injunção, ministro Marco Aurélio, frisou em seu voto que concedia a ordem, nos moldes da decisão da Corte no MI 758 (ver matéria abaixo), mas deixando claro que cabe ao setor administrativo responsável a comprovação de cada situação, para verificar se o servidor atende aos requisitos constantes da Lei 8.213/91, que dispõe sobre os Planos de Benefícios da Previdência Social. 'Eu apenas fixo os parâmetros para a aposentação, se o impetrante realmente atender aos requisitos da Lei 8.213/91. Eu não posso, no mandado de injunção, apreciar esse aspecto, se ele atende ou não aos requisitos. Isso ficará por conta do setor administrativo definir', explicou o relator.

Além disso, o ministro fez questão de deixar clara a impossibilidade de se criar um terceiro sistema, mesclando a Constituição Federal e a Lei 8.213/91, conforme foi decidido pelo pleno no julgamento de embargos declaratórios no MI 758.

Foram julgados na tarde desta segunda-feira (2) os Mls 835, 885, 923, 957, 975, 991, 1.083, 1.128, $1.152,1.182$, 1.270, 1.440, 1.660, 1.681, 1.682, 1.700, 1.747, 1.797, 1.800, 1.835 e 2.426". 
Notamos por via de consequência que o aspecto de maior relevo na tutela jurídica constitucional do tema ora enfocado está relacionado à saúde da pessoa humana 2425 e 26 em harmonia com o art. 1으, III, da Carta da República ${ }^{27}$ e 28.

24 ARE 664335/ SC - SANTA CATARINA RECURSO EXTRAORDINÁRIO COM AGRAVO Relator(a): Min. LUIZ FUX Julgamento: 04/12/2014 Órgão Julgador: Tribunal Pleno. Publicação ACÓRDÃO ELETRÔNICO. REPERCUSSÃO GERAL - MÉRITO. DJe-029 DIVULG 1102-2015 PUBLIC 12-02-2015. Ementa: RECURSO EXTRAORDINÁRIO COM AGRAVO. DIREITO CONSTITUCIONAL PREVIDENCIÁRIO. APOSENTADORIA ESPECIAL. ART. 201, § 1ㅇ, DA CONSTITUIÇÃO DA REPÚBLICA. REQUISITOS DE CARACTERIZAÇÃO. TEMPO DE SERVIÇO PRESTADO SOB CONDIÇÕES NOCIVAS. FORNECIMENTO DE EQUIIPAMENTO DE PROTEÇĂO INDIVIDUAL - EPI. TEMA COM REPERCUSSÃO GERAL RECONHECIDA PELO PLENÁRIO VIRTUAL. EFETIVA EXPOSIÇÃO A AGENTES NOCIVOS À SAÚDE. NEUTRALIZAÇÃO DA RELAÇÃO NOCIVA ENTRE O AGENTE INSALUBRE E O TRABALHADOR. COMPROVAÇÃO NO PERFIL PROFISSIOGRÁFICO PREVIDENCIÁRIO PPP OU SIMILAR. NÃO CARACTERIZAÇÃO DOSPRESSUPOSTOS HÁBEIS À CONCESSÃO DE APOSENTADORIA ESPECIAL. CASO CONCRETO. AGENTE NOCIVO RUÍDO. UTILIZAÇÃO DE EPI. EFICÁCIA. REDUÇÃO DA NOCIVIDADE. CENÁRIO ATUAL. IMPOSSIBILIDADE DE NEUTRALIZAÇÃO. NÃO DESCARACTERIZAĈ̃O DAS CONDIC̄ÕES PREJUDICIAIS. BENEFÍCIO PREVIDENCIÁRIO DEVIDO. AGRAVO CONHECIDO PARA NEGAR PROVIMENTO AO RECURSO EXTRAORDINÁRIO. 1. Conduz à admissibilidade do Recurso Extraordinário a densidade constitucional, no aresto recorrido, do direito fundamental à previdência social (art. 201, CRFB/88), com reflexos mediatos nos

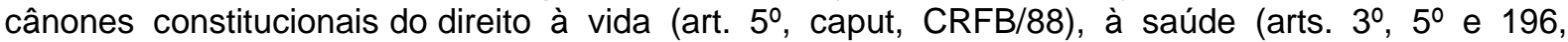
$\mathrm{CRFB} / 88$ ), à dignidade da pessoa humana (art. $1^{\circ}$, III, CRFB/88) e ao meio ambiente de trabalho equilibrado (arts. 193 e 225, CRFB/88). 2. A eliminação das atividades laborais nocivas deve ser a meta maior da Sociedade - Estado, empresariado, trabalhadores e representantes sindicais -, que devem voltar-se incessantemente para com a defesa da saúde dos trabalhadores, como enuncia a Constituição da República, ao erigir como pilares do Estado Democrático de Direito a dignidade humana (art. 10, III, CRFB/88), a valorização social do trabalho, a preservação da vida e da saúde (art. 3o 5으, e 196, CRFB/88), e o meio ambiente de trabalho equilibrado (art. 193, e 225, CRFB/88). 3. A aposentadoria especial prevista no artigo 201, § 1ํㅡㄹ da Constituição da República, significa que poderão ser adotados, para concessão de aposentadorias aos beneficiários do regime geral de previdência social, requisitos e critérios diferenciados nos "casos de atividades exercidas sob condições especiais que prejudiquem a saúde ou a integridade física, e quando se tratar de segurados portadores de deficiência, nos termos definidos em lei complementar". 4. A aposentadoria especial possui nítido caráter preventivo e impõe-se para aqueles trabalhadores que laboram expostos a agentes prejudiciais à saúde e a fortiori possuem um desgaste naturalmente maior, por que não se lhes pode exigir o cumprimento do mesmo tempo de contribuição que aqueles empregados que não se encontram expostos a nenhum agente nocivo. 5. A norma inscrita no art. 195, § 5, CRFB/88, veda a criação, majoração ou extensão de benefício sem a correspondente fonte de custeio, disposição dirigida ao legislador ordinário, sendo inexigível quando se tratar de benefício criado diretamente pela Constituição. Deveras, o direito à aposentadoria especial foi outorgado aos seus destinatários por norma constitucional (em sua origem o art. 202, e atualmente o art. 201, § 1ํㅡ, CRFB/88). Precedentes: RE 151.106 AgR/SP, Rel. Min. Celso de Mello, julgamento em 28/09/1993, Primeira Turma, DJ de 26/11/93; RE 220.742, Rel. Min. Néri da Silveira, julgamento em 03/03/98, Segunda Turma, DJ de 04/09/1998. 6. Existência de fonte de custeio para o direito à aposentadoria especial antes, através dosinstrumentos tradicionais de financiamento da previdência social mencionados no art. 195, da CRFB/88, e depois da Medida Provisória oㅜ 1.729/98, posteriormente convertida na Lei no 9.732, de 11 de dezembro de 1998. Legislação que, ao reformular o seu modelo de financiamento, inseriu os $\S \S$ $6^{\circ}$ e $7^{\circ}$ no art. 57 da Lei n. $.8 .213 / 91$, e estabeleceu que este benefício será financiado com recursos provenientes da contribuição de que trata o inciso II do art. 22 da Lei ํo 8.212/91, cujas alíquotas serão acrescidas de doze, nove ou seis pontos percentuais, conforme a atividade exercida pelo segurado a serviço da empresa permita a concessão de aposentadoria especial após quinze, vinte ou vinte e cinco anos de contribuição, respectivamente. 7. Por outro lado, o art. 10 da Lei № 10.666/2003, ao criar o Fator Acidentário de Prevenção-FAP, concedeu redução de até $50 \%$ do valor desta contribuição em favor das empresas que disponibilizem aos seus empregados equipamentos de proteção declarados eficazes nos formulários previstos na legislação, o qual funciona como incentivo para que as empresas 
continuem a cumprir a sua função social, proporcionando um ambiente de trabalho hígido a seus trabalhadores. 8. O risco social aplicável ao benefício previdenciário da aposentadoria especial é o exercício de atividade em condições prejudiciais à saúde ou à integridade física (CRFB/88, art. 201, § $1^{\circ}$ ), de forma que torna indispensável que o indivíduo trabalhe exposto a uma nocividade notadamente capaz de ensejar o referido dano, porquanto a tutela legal considera a exposição do segurado pelo risco presumido presente na relação entre agente nocivo e o trabalhador. 9. A interpretação do instituto da aposentadoria especial mais consentânea com o texto constitucional é aquela que conduz a uma proteção efetiva do trabalhador, considerando o benefício da aposentadoria especial excepcional, destinado ao segurado que efetivamente exerceu suas atividades laborativas em "condições especiais que prejudiquem a saúde ou a integridade física". 10. Consectariamente, a primeira tese objetiva que se firma é: o direito à aposentadoria especial pressupõe a efetiva exposição dotrabalhador a agente nocivo à sua saúde, de modo que, se o EPI for realmente capaz de neutralizar a nocividade não haverá respaldo constitucional à aposentadoria especial. 11. A Administração poderá, no exercício da fiscalização, aferir as informações prestadas pela empresa, sem prejuízo do inafastável judicial review. Em caso de divergência ou dúvida sobre a real eficácia do Equipamento de Proteção Individual, a premissa a nortear a Administração e o Judiciário é pelo reconhecimento do direito ao benefício da aposentadoria especial. Isto porque o uso de EPI, no caso concreto, pode não se afigurar suficiente para descaracterizar completamente a relação nociva a que o empregado se submete. 12. In casu, tratando-se especificamente do agente nocivo ruído, desde que em limites acima do limite legal, constata-se que, apesar do uso de Equipamento de Proteção Individual (protetor auricular) reduzir a agressividade do ruído a um nível tolerável, até no mesmo patamar da normalidade, a potência do som em tais ambientes causa danos ao organismo que vão muito além daqueles relacionados à perda das funções auditivas. O benefício previsto neste artigo será financiado com os recursos provenientes da contribuição de que trata o inciso II do art. 22 da Lei no 8.212, de 24 de julho de 1991, cujas alíquotas serão acrescidas de doze, nove ou seis pontos percentuais, conforme a atividade exercida pelo segurado a serviço da empresa permita a concessão de aposentadoria especial após quinze, vinte ou vinte e cinco anos de contribuição, respectivamente. O benefício previsto neste artigo será financiado com os recursos provenientes da contribuição de que trata o inciso II do art. 22 da Lei no 8.212, de 24 de julho de 1991, cujas alíquotas serão acrescidas de doze, nove ou seis pontos percentuais, conforme a atividade exercida pelo segurado a serviço da empresa permita a concessão de aposentadoria especial após quinze, vinte ou vinte e cinco anos de contribuição, respectivamente. 13. Ainda que se pudesse aceitar que o problema causado pela exposição ao ruído relacionasse apenas à perda das funções auditivas, o que indubitavelmente não é o caso, é certo que não se pode garantir uma eficácia real na eliminação dos efeitos doagente nocivo ruído com a simples utilização de EPI, pois são inúmeros os fatores que influenciam na sua efetividade, dentro dos quais muitos são impassíveis de um controle efetivo, tanto pelas empresas, quanto pelos trabalhadores. 14. Desse modo, a segunda tese fixada neste Recurso Extraordinário é a seguinte: na hipótese de exposição do trabalhador a ruído acima dos limites legais de tolerância, a declaração do empregador, no âmbito doPerfil Profissiográfico Previdenciário (PPP), no sentido da eficácia do Equipamento de Proteção Individual - EPI, não descaracteriza o tempo de serviço especial para aposentadoria. 15. Agravo conhecido para negar provimento ao Recurso Extraordinário.

${ }_{25}$ Vide ADPF 101, Rel. Min. Cármen Lúcia, j. em 11-3-2009, Plenário, Informativo 538.

26 "Acontece que esse caso me parece peculiar, e muito peculiar - se o superlativo for admitido eu diria peculiaríssimo -, porque a lei federal faz remissão à Convenção da OIT 162, art. $3 \stackrel{0}{=}$, que, por versar tema que no Brasil é tido como de direito fundamental (saúde), tem o status de norma supralegal. Estaria, portanto, acima da própria lei federal que dispõe sobre a comercialização, produção, transporte, etc., do amianto. (...) De maneira que, retomando o discurso do Ministro Joaquim Barbosa, a norma estadual, no caso, cumpre muito mais a Constituição Federal nesse plano da proteção à saúde ou de evitar riscos à saúde humana, à saúde da população em geral, dos trabalhadores em particular e do meio ambiente. A legislação estadual está muito mais próxima dos desígnios constitucionais, e, portanto, realiza melhor esse sumo princípio da eficacidade máxima da Constituição em matéria de direitos fundamentais, e muito mais próxima da OIT, também, do que a legislação federal. Então, parece-me um caso muito interessante de contraposição de norma suplementar com a norma geral, levando-nos a reconhecer a superioridade da norma suplementar sobre a norma geral. E, como estamos em sede de cautelar, há dois princípios que desaconselham o referendum à cautelar: o princípio da precaução, que busca evitar riscos ou danos à saúde e ao meio ambiente para gerações presentes; e o princípio da prevenção, que tem a mesma finalidade para gerações futuras. Nesse caso, portanto, o periculum in mora é invertido e a plausibilidade do 


\section{Com efeito}

Todo ser humano tem direito a uma vida digna, princípio constitucional explicitamente previsto no Art. $1^{\circ}$, III de nossa Lei Maior.

A concretização desse direito fundamental reclama a observação de outras tantas normas atreladas ao preceito. Entre elas, encontramos as relativas à proteção da saúde do trabalhador, conforme já observamos no art. 7트, XXII e XXIII, da Constituição Federal. Além disso, um pouco mais à frente, prescreve o legislador que o Sistema Único de Saúde tem, entre outras funções, a atribuição de "[...] executar as ações de vigilância sanitária e epidemiológica, bem como de saúde do trabalhador". No tocante à matéria relativa ao meio ambiente do trabalho, continua ela a ser

direito também contraindica o referendum a cautelar. Senhor Presidente, portanto, pedindo todas as vênias, acompanho a dissidência e também não referendo a cautelar" (ADI 3.937-MC, Rel. Min. Marco Aurélio, voto do Min. Carlos Britto, julgamento em 4-6-2008, Plenário, DJE de 10-10-2008).

${ }^{27}$ Como meio de concretizar o princípio da dignidade da pessoa humana e do direito à vida e à saúde, entendeu o Superior Tribunal de Justiça ser possível inclusive conceder liminar garantindo antecipadamente (antecipação de tutela) o bloqueio de valores em contas públicas para garantir o custeio de tratamento médico indispensável (vide REsp 820.674, Relatora Ministra Eliana Calmon; Órgão Julgador: Segunda Turma; Data do julgamento: 18-5-2006).

28 Por sete votos a três o Supremo Tribunal Federal manteve em junho de 2008 a vigência da Lei paulista n. 12.684/2007 que proibiu o uso de qualquer produto que utilize o amianto no Estado, tendo sido observado na oportunidade, pela maioria dos ministros, que referida norma estadual estaria em conformidade com a Constituição Federal atendendo ao princípio da proteção à saúde.

Vide ADI 3.937. 
basicamente regulada pela Consolidação das Leis do Trabalho 293031 e pela Portaria n. 3.214/78, que aprova diversas normas regulamentadoras (NR) concernentes à

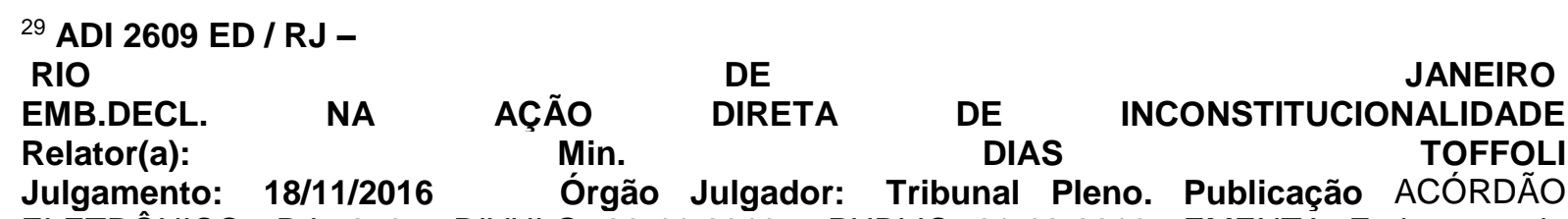
ELETRÔNICO. DJe-256 DIVULG 30-11-2016 PUBLIC 01-12-2016. EMENTA Embargos de declaração. Ação direta de inconstitucionalidade. Lei no 3.623/01 do Estado do Rio de Janeiro. Critérios de proteção do meio ambiente do trabalho e da saúde do trabalhador. Natureza trabalhista dos temas tratados na lei. Competência privativa da União para legislar sobre direito do trabalho. Inexistência de omissão, contradição ou obscuridade. Rediscussão de temas já debatidos em julgamento de mérito. Embargos de declaração rejeitados. 1. Não há omissão ou obscuridade no acórdão embargado quanto à natureza da matéria tratada na Lei estadual no 3.623/01 e à alegada possibilidade de o Estado regulamentar critérios para a manutenção da saúde dos trabalhadores. No julgamento da presente ação direta, restou assentada a natureza trabalhista dos temas tratados na lei do Estado do Rio de Janeiro, motivo pelo qual foi reconhecida a usurpação da competência privativa da União para legislar sobre direito do trabalho. Também foi afastada a possibilidade de o Estado do Rio de Janeiro, com fundamento na competência concorrente prevista na Carta da República, legislar sobre as matérias veiculadas no citado diploma legal, uma vez que essa competência não abrange a disciplina acerca da saúde dostrabalhadores e do meio ambiente do trabalho. 2. Não estão presentes quaisquer das hipóteses autorizadoras da oposição dos embargos de declaração. $\mathrm{Na}$ realidade, pretende a embargante rediscutir a decisão invocando matérias já enfrentadas no acórdão atacado, fim para o qual não se presta o recurso aclaratório. 3. Embargos declaratórios rejeitados.

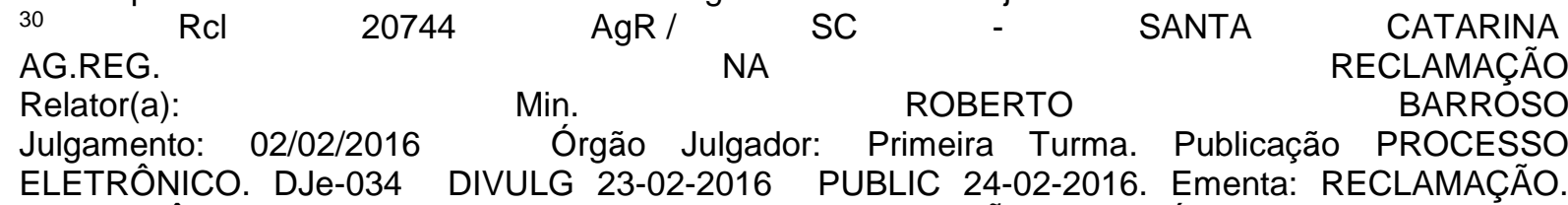
COMPETÊNCIA DA JUSTIÇA DO TRABALHO. ADI 3.395. AÇÃO CIVIL PÚBLICA. CUMPRIMENTO DE NORMAS DE SAÚDE, SEGURANÇA E HIGIENE NO TRABALHO. 1. Não há identidade estrita com o decidido na ADI 3.395-MC o debate sobre a competência da Justiça do Trabalho para julgar ação civil pública, cujo objetivo é impor a ente público o cumprimento de normas relativas ao meio ambiente do trabalho (no caso, hospital público no qual trabalham não apenas servidores estatutários, mas também funcionários terceirizados, submetidos à CLT). 2. Agravo regimental desprovido.

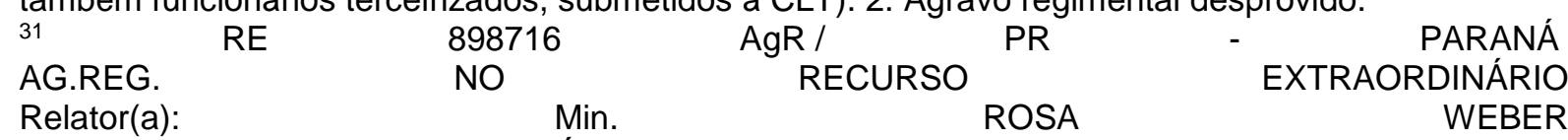

Julgamento: 29/09/2015 Órgão Julgador: Primeira Turma Publicação PROCESSO ELETRÔNICO. DJe-205 DIVULG 13-10-2015 PUBLIC 14-10-2015. EMENTA DIREITO AMBIENTAL E PROCESSUAL CIVIL. AÇÃO CIVIL PÚBLICA. RESPONSABILIDADE POR DANO AO MEIO AMBIENTE. VAZAMENTO DE ÓLEO DO OLEODUTO DA REPAR QUE ATINGIU O RIO IGUAÇU. COMPETÊNCIA DA JUSTIÇA FEDERAL FIRMADA NO ACÓRDÃO DE ORIGEM. REELABORAÇÃO DA MOLDURA FÁTICA. PROCEDIMENTO VEDADO NA INSTÂNCIA EXTRAORDINÁRIA. NEGATIVA DE PRESTAÇÃO JURISDICIONAL. ART. 93, IX, DA CONSTITUIÇÃO DA REPÚBLICA. NULIDADE. INOCORRÊNCIA. RAZÕES DE DECIDIR EXPLICITADAS PELO ÓRGÃO JURISDICIONAL. ALEGAÇÃO DE OFENSA AO ART. 5, LIV E LV, DA CONSTITUIÇÃO DA REPÚBLICA. CONTRADITÓRIO E AMPLA DEFESA. DEVIDO PROCESSO LEGAL. NATUREZA INFRACONSTITUCIONAL DA CONTROVÉRSIA. SÚMULAS 282 E 356 DO SUPREMO TRIBUNAL FEDERAL. AUSÊNCIA DE PREQUESTIONAMENTO. ACÓRDÃO RECORRIDO PUBLICADO EM 13.4.2010. 1. Inexiste violação do art. 93, IX, da Constituição Federal. A jurisprudência do Supremo Tribunal Federal é no sentido de que o referido dispositivo constitucional exige a explicitação, pelo órgão jurisdicional, das razões do seu convencimento, dispensando o exame detalhado de cada argumento suscitado pelas partes. 2. Obstada a análise da suposta afronta aos incisos LIV e LV do art. 5o da Carta Magna, porquanto dependeria de prévia análise da legislação infraconstitucional aplicada à espécie, procedimento que refoge à competência jurisdicional extraordinária desta Corte Suprema, a 
segurança e medicina do trabalho. Interessante verificar que a Consolidação traz um capítulo específico para a segurança e medicina do trabalho, prevendo diversos modos de conservação do meio ambiente e prevenção de acidentes e doenças do trabalho. Impõe deveres aos empregados e empregadores, bem como aos órgãos da Administração Pública.

De uma forma geral, verificamos o empenho do Estado em regular as condutas para a preservação e conservação do meio ambiente laboral, todavia, não se pode deixar de criticar a "tarifação" feita por conta dos trabalhos insalubres e perigosos, atribuindo-se valores ínfimos e que jamais compensariam os prejuízos experimentados pelo trabalhador.

Por outro lado, conforme já tivemos também a oportunidade de destacar, cabe questionar, para fins de proteção ambiental, qual o conceito de trabalho que se deve adotar. Sendo o meio ambiente sadio um direito constitucional fundamental, o conceito de trabalhador também deve ser perquirido no seio da Carta Magna. O ponto de partida a ser adotado é que a proteção ao meio ambiente do trabalho é distinta da proteção do direito do trabalho. Isso porque aquela tem por objeto jurídico a saúde e a segurança do trabalhador, a fim de que este possa desfrutar uma vida com qualidade. Busca-se salvaguardar o homem trabalhador das formas de degradação e poluição de vida.

Num segundo momento, deve-se observar que se valoriza o trabalho humano, porquanto este é direito social fundamentador da ordem econômica e financeira e um dos fundamentos da República Federativa do Brasil. Mas o trabalho tem de estar relacionado a um aspecto econômico, uma vez que deve ser passível de valoração social. Nesse contexto, pode-se concluir que

teor do art. 102 da Magna Carta. 3. Cristalizada a jurisprudência desta Suprema Corte, a teor das Súmulas 282 e 356/STF: "Inadmissível o recurso extraordinário, quando não ventilada, na decisão recorrida, a questão federal suscitada", bem como "O ponto omisso da decisão, sobre o qual não foram opostos embargos declaratórios, não pode ser objeto de recurso extraordinário, por faltar o requisito do prequestionamento." 4. O Tribunal Regional Federal da $4^{a}$ Região firmou ser da Justiça Federal a competência para analisar as questões quanto ao acidente de trabalho provocador do dano ambiental de grande dimensão - vazamento de 4 milhões de óleo do oleoduto da Repar (Refinaria Presidente Getúlio Vargas), que atingiu o Rio Iguaçu - e quanto à proteção ao meio ambiente do trabalho, "pois não há como dissociar o acidente do seu entorno, ou seja, as matérias estão entrelaçadas e devem ser decididas conjuntamente. O objetivo da ação civil pública é maior, que é o de alcançar, com a compatibilização do meio ambiente de trabalho, meios eficazes para prevenir novos danos ao meio ambiente e, diante deste contexto, não há como cindir o processo. Não se trata, portanto, de analisar questões meramente trabalhistas, da seara do direito do trabalho". Divergir desse entendimento exigiria o revolvimento do quadro fático delineado no acórdão de origem, procedimento vedado em sede extraordinária. 5 . As razões do agravo regimental não se mostram aptas a infirmar os fundamentos que lastrearam a decisão agravada. 6. Agravo regimental conhecido e não provido. 


\begin{abstract}
[...] o trabalho adquire no Texto Constitucional inúmeras feições, que, embora diferentes, são ligadas entre si e complementares aos objetivos e fundamentos da República no sentido de assegurar a todos uma existência digna num sistema onde haja justiça social. Assim, ora o trabalho surge enquanto instrumento de tutela pessoal, essencial à sobrevivência do homem indivíduo (por exemplo, o direito social ao trabalho), ora surge enquanto política a ser implementada pelo Estado, numa dimensão difusa e essencial aos objetivos apregoados pelo Estado Democrático de Direito (COELHO, 1995).
\end{abstract}

De qualquer forma, como advertem Celso Fiorillo e Renata Ferreira (2018) jamais se deve restringir a proteção ambiental trabalhista a relações de natureza unicamente empregatícia. Quando se fala em relação de emprego está-se referindo àqueles vínculos em que o trabalho é subordinado. Em diversas passagens da Constituição Federal, podemos observar que o legislador sempre alude à relação de trabalho, ou seja, àquela em que há prestação de serviços, seja de natureza subordinada ou não. Quando quis referir-se à relação de emprego, assim o fez expressamente, como ocorre, por exemplo, no art. $7 \underline{\underline{0}}$, I.

O que interessa, na lição de referidos autores é a proteção ao meio ambiente onde o trabalho humano é prestado, seja em que condição for. Estão protegidos, portanto, por exemplo, os vendedores autônomos e os trabalhadores avulsos.

\title{
CONCLUSÃO
}

As Empresas que prestam serviços a terceiros em face das atividades previstas no âmbito da ordem econômica constitucional, balizadas que estão pelos próprios princípios gerais da atividade econômica descritos no TíTULO VII - Da Ordem Econômica e Financeira - CAPÍTULO I - DOS PRINCÍPIOS GERAIS DA ATIVIDADE ECONÔMICA ,submetem-se ao que determina o princípio da defesa do meio ambiente (Art.170, VI da CF), cujo conteúdo constitucional está descrito no Art.225 da CF, inclusive mediante tratamento diferenciado conforme o impacto ambiental (Art.225, parágrafo 1ํㅣㄴ IV) dos produtos e serviços e de seus processos de elaboração e prestação. Destarte, estão sujeitas à obrigação de reparar danos 
causados no âmbito da tutela jurídica constitucional vinculada ao meio ambiente do trabalho/saúde ambiental em face de responsabilidade não só objetiva como solidária.

\section{REFERÊNCIAS}

AFIFI, A. \& BRESLOW, L. The mature paradigm of public health. Ann. Rev. Public Health, 15:223-35, 1994.

ALONSO, Marta Leon. La protección constitucional de la salud. Editorial: La Ley Actualidad. Madrid. España.2010.

AÑóN, Carlos Lema. Apogeo y crisis de la ciudadanía de la salud: historia del derecho a la salud en el siglo XX. Editorial Dykinson. Madrid. España.2012.

AÑóN, Carlos Lema. Salud, justicia, derechos el derecho a la salud como derecho social. Editorial Dykinson. Madrid. España.2010.

BRASIL. ADI 3.540-MC, Rel. Min. Celso de Mello, julgamento em 1ํ-9-2005, Plenário, $D J$ de 3-2-2006

Al 805.018 AgR/SC, 1ํㅡ Turma, Min. Dias Toffoli, j. em 25-9-2012.

ADI 1003-MC, Rel. Min. Celso de Mello, DJ, 10-9-1999.

Supremo Tribunal Federal. HC 89.878, Rel. Min. Eros Grau, j. em 20-4-2010, 2른 Turma, DJe, 14-5-2010.

$\overline{\text { DJe de }} 4 \cdot \overline{12-2012 .}$

. HC 111.762/RO, 2aㅡ., Rel. Min. Cármen Lúcia, j. em 13-11-2012,

RE 214.001 AgR/SP, 2aㅡ Turma, Min. Teori Zavascki, j. em 27-8-2013.

RE 548.181, rel. min. Rosa Weber, j. 6-8-2013, 1a T, DJE de 30-10-2014.

de 5-3-2013

RE 679.676 AgR/PR, 2aㅡ., Rel. Min. Cármem Lúcia, j. em 19-2-2013, DJe

REsp 107.174-1-SP, rel. Min. Herman Benjamin, de 9-7-2008.

CAPPELLETTI, Mauro Formazioni. sociali e interessi di gruppo davanti alla giustizia civile. Padova: CEDAM, 1975.

CASAS, W.J.P.; CORDEIRO, E.P.; MELLO, T.C.; ZANNIN, P.H.T. Noise mapping as a tool for controlling industrial noise pollution. Journal of Scientific\& Industrial Research, New Delhi, v. 73 
COELHO, Elaine D'Ávila. Embargo, interdição e greve em face do meio ambiente do trabalho. Monografia da disciplina de Direito Ambiental II, ministrada pelo Prof.Dr.Celso Antonio Pacheco Fiorillo ,PUCSP, 1995.

EVANS, T. et al. Challenging inequities in health from ethics to action. Oxford: Oxford University Press, 2001.

FIORILLO, Celso Antonio Pacheco. Curso de Direito Ambiental Brasileiro, 19 edição, revista, ampliada e atualizada São Paulo: Saraiva, 2019.

. Comentário ao Artigo 170, VI da Constituição Federal-Defesa do Meio Ambiente como Princípio da Atividade Economica. In: J.J.Gomes Canotilho e outros. (Org.). Comentários à Constituição do Brasil. 2ed.São Paulo: Saraiva, 2018, v. 1.

Direito Processual Ambiental Brasileiro - A defesa judicial do patrimônio genético, do meio ambiente cultural, do meio ambiente digital, do meio ambiente artificial, do meio ambiente do trabalho e do meio ambiente natural no Brasil.

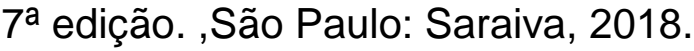

Saraiva, 2000

O Direito de Antena em face do Direito Ambiental no Brasil. São Paulo:

; FERREIRA, Renata Marques. Tutela Jurídica da Saúde em face do Direito Ambiental Brasileiro-Saúde Ambiental e Meio Ambiente do Trabalho. Rio de Janeiro : Lumen Juris, 2018.

GIANNINI MS Ambiente. saggio sui dibersi suoi aspetti giuridici Riv. Trim.Dir.Pubbl. Milano: Giuffre',1973

GIANPIETRO F . La responsabilità per danno all'ambiente. Milano: Giuffré, 1988

MALINCONICO, Carlo. Beni Ambientali. Padova: CEDAM, 1991.

MORENO-JIMENEZ, Bernardo; GARROSA HERNANDEZ, Eva. Salud laboral riesgos laborales psicosociales y bienestar laboral. Ediciones Pirámide. Madrid. España.2013.

NERY,Rosa Indenização do dano ambiental (responsabilidade civil e ação civil pública). Dissertação de Mestrado da PUCSP, 1993.

NÚÑEZ-CORTÉS CONTRERAS, Pilar; LOUSADA AROCHENA, José Fernando. La vigilancia de la salud laboral. Editorial Tecnos. Madrid. España.2016

PRIEUR, Michel. Droit de l'environnement Avec la collaboration de Julien Bétaille, Marie-Anne Cohendet, Hubert Delzangles, Jessica Makowiak, Pascale Steichen. 7e edition Paris : Dalloz/2016.

PÉREZ GÁLVEZ, Juan Francisco BARRANCO VELA, Rafael. Derecho y salud en la Unión Europea. Editorial Comares. Granada. España.2013. 
RIVAS VALLEJO, Pilar; MONEREO PÉREZ, José Luiz; GARCIA VALVERDE, Maria Dolores. Tratado de la salud laboral/Tomo I: Aspectos jurídicos de la prevención de riesgos laborales. Editorial Aranzadi. Pamplona. España.2012.

SANDRONI, Paulo. Novíssimo dicionário de economia. São Paulo:Editora Best Seller, 1999. 